\title{
Investigating the Predictors and Outcomes of Entrepreneurial Bricolage
}

\author{
Sumera Asgher Butt ${ }^{\text {a }}$, Zulfiqar Ahmed Bowra ${ }^{\text {b }}$, Naveed Iqbal Chaudhry ${ }^{c}$ \\ ${ }^{\text {a }}$ Ph.D. Scholar, Hailey College of Commerce, University of the Punjab, Lahore Pakistan \\ Email: samera.bilal@pugc.edu.pk \\ ${ }^{\mathrm{b}}$ Principal, Hailey College of Commerce, University of the Punjab Lahore, Pakistan \\ Email: zulfiqar.hcc@pu.edu.pk \\ ${ }^{c}$ Associate Professor, Department of Business Administration, University of the Punjab, Gujranwala \\ Campus, Pakistan \\ Email: Naveed.iqbal@pugc.edu.pk
}

\begin{tabular}{l}
\hline ARTICLE DETAILS \\
\hline History: \\
Accepted 29 July 2021 \\
Available Online September 2021
\end{tabular}

\section{Keywords:}

Investigating, Predictors,

Outcomes, Entrepreneurial

Bricolage

\section{JEL Classification:}

L26, L29

DOI: $10.47067 /$ reads.v7i3.370

\begin{abstract}
Entrepreneurial leaders have the ability to influence business model innovation and entrepreneurial bricolage. Introducing alternative ideas and behaviors in an enterprise nowadays often linked to innovation. Companies are eager to take advantage of or benefit from new goods or services or technological marketing channels in this context. Due to the recognition of leadership as an important driver of business innovation, a perceptual framework has been established in order to study the consequences of entrepreneurial leadership on the desire to build business model innovation in organizations, with business acting as a mediating moderating function on entrepreneurial bricolage and entrepreneurial self-efficacy. To explore the conceptual model of the study, five hypotheses have been proposed. A self-managed survey was conceived to acquire cross-sectional responses from 325 people working in the Punjab, Pakistan manufacturing industry. The results demonstrated that, when entrepreneurial self-efficacy is high, the link between entrepreneurial leadership and business model innovation models is stronger. As a result, this is a one-of-a-kind cross-sectional study that investigates the mediating-moderating process of business bricolage and entrepreneurial self-efficacy in Pakistan's manufacturing industry. The study contributes to existing research while also assisting legislators in taking action to govern workplace self-efficacy and encouraging leaders to use entrepreneurial bricolage techniques and business model innovation.
\end{abstract}

(C) 2021 The authors. Published by SPCRD Global Publishing. This is an open access article under the Creative Commons Attribution-

NonCommercial 4.0

Corresponding author's email address: samera.bilal@pugc.edu.pk

\section{Introduction}

A sort of "entrepreneur" leader that is different from previous styles of behavioral leadership is needed in the increasingly unstable and competitive environment that business companies face (Gupta 


\section{Review of Economics and Development Studies, Vol. 7 (3) 2021, 343-356}

et al., 2004). Leadership includes entrepreneurial ideals enterprise, enterprising purpose and entrepreneurial administration (Covin \& Slevin, 1988; Miller, 2011; Schumpeter \& Nichol, 1934; Stevenson, 1983). It takes a comprehensive orientation to entrepreneurship in order for entrepreneurial initiatives to encourage the development of better skills for continuously creating and subverting real worth. As a result, entrepreneurship would include a basis for significant advantage and technological growth in all types of businesses looking for leadership and productivity in the new era. Entrepreneurial leadership is an individual who can reorganize their business to take advantage of new chances and increase their capacity to develop strategies to compete in a highly uncertain environment (Huang et al., 2014). (Gupta et al., 2004) defined three-dimensional entrepreneurial leadership, innovation (to encourage creativeness between team members and to produce new goods and services), pro activeness (to motivate people to compete with other firms) and risk taking (eagerness to face ambiguity and take liability). Entrepreneurship leadership seems to have a connection with strong organizational growth, because it generates a competitive edge and guarantees sustainability (Palalic, 2017). Nonetheless, there have been few studies on the relationship between entrepreneurial leadership and business model innovation, so this association needs to be investigated in this research.

Business models have often evolved, but in latest days, professionals and legal scholars were much more interested in them. We're hearing even more from businesses - adults and kids, from a variety of industries - where business model creativity has become a core factor of growth. Although brilliant and successful business models frequently seem to have gotten right from the president's desk to execution, enabling the organization to fame and wealth, modern business models usually fail the first run around, as legislators overcome difficulty at both investigative and development phases. Organizations are facing the complexity and randomness of rapidly environments at the observational period, as their new business plan has been conceptualized; additionally, began developing their psychological models of the world on small or incomplete perceptual images, they will be hindered through their own "analogical reasoning." New business models necessitate organizational reconfiguration at the transition period, which necessitates legislators mobilizing raw materials, developing specialized skill sets, and adjusting organizational processes to facilitate training, improvement, and transformation. It is commonly recognized that entrepreneurs have to establish business limits and identify the product/service they want to offer throughout the initiating phase (Trimi \& Berbegal-Mirabent, 2012) This is a particularly tough challenge for new technological firms, which often need major expenditures and have a limited period to develop the concept into a full-time enterprise, avoiding product obsolescence (Trimi \& Berbegal-Mirabent, 2012). Innovation is defined as a drive to accomplish things in a more imaginative way. In the context of a business, innovation refers to the fusion of a variety of current methods that enable a firm to accomplish and outperform its competitors (Al-Ansari et al., 2014). For example, just because of product innovation and business model innovation (BMI) Apple organization has become the center of market attraction and cover 30 times larger than its original market. In organizations, entrepreneurial leadership is accessing the circumstances and identifying the best ideas, preparing the organization for projects to be tackled and selecting the best for scale-up, and then systematizing these one-time efforts by constructing the platforms and skills required (Lindgardt et al., 2009). However, a few tasks are critical in these phases in order to seek business model innovation (BMI) (Lindgardt et al., 2009), but with the help of entrepreneurial leaders, followers can cope with those critical phases.

The majority of entrepreneurs experience major budget constraints (Shepherd et al., 2000). Most creative companies, as (Aldrich, 1999; Aldrich et al., 1941)lamented, "Can't always seem to get whatever they want, and definitely might not get everything they need." Insufficient capital, relational, contextual, and some other asset protections are used to build the harmonic company (Bourgeois III \& 


\section{Review of Economics and Development Studies, Vol. 7 (3) 2021, 343-356}

Eisenhardt, 1988; Brüderl et al., 1992). Bricolage habits have been described as a means for certain businesses to "make do" by combining capital available to solve new problems (Baker \& Nelson, 2005). Bricolage behaviors which are effective can aid in the growth of companies that are capable of handling price swings, succeed, and maybe even resilience in the face limited funding. In the last decade, bricolage has emerged as one of the most important principles in entrepreneurial education for understanding entrepreneurs' dynamic behavior and methods in resource creation and use.

The extent to which consumers believe they have the potential to effectively fulfill the different duties of entrepreneurship is known as entrepreneurial self-efficacy (ESE) to partake in the new business economic growth with no need for a minimum degree of entrepreneurial self-efficacy (Boyd \& Vozikis, 1994; Krueger Jr \& Brazeal, 1994; Markman et al., 2002; Zhao et al., 2005).Possible future founders are unable to be adequately inspired self-efficacy also enjoys (Judge \& Bono, 2001; Stajkovic \& Luthans, 1998). People who have high levels of self-efficacy, for instance, are more prepared to follow imperfect market, stick to them even in the midst of adversity, and rebound rapidly from disappointment. The above advantages are probably to be especially beneficial in the world of contemporary entrepreneurial intention, which is marked by increasing magnitude, absolutely imperative demand, and knowledge exposure (Baron, 1998). As a result, it's really no surprise that entrepreneurs with strong entrepreneurial self-efficacy experience better financial performance (Bradley \& Roberts, 2004) and drive their companies to increased sales and labor productivity (Baum \& Locke, 2004; Baum et al., 2001) while those with poor entrepreneurial self-efficacy cannot make their

performance better. The first part of this study is to look at the influence of entrepreneurial leadership on innovation of the business model as well as the link between entrepreneurial leadership and self-efficiency (Renko et al., 2015) on entrepreneurial bricolage where self-efficacy is a moderator between entrepreneurial leadership and bricolage, and bricolage plays a mediating role between Business model innovation (BMI) and entrepreneurial leadership.

\section{Literature Review and Development of Hypothesis}

\subsection{Entrepreneurial leadership and Business Model Innovation}

A lot of entrepreneurship research has looked at how entrepreneurial leadership affects growth, imagination, learning, and business efficiency (Covin \& Slevin, 1989; Huang et al., 2014; Wiklund \& Shepherd, 2005; Zahra, 1991). Leadership is considered as having a significant impact on creativity and imagination (Yukl et al., 2013). We describe entrepreneurial leadership as a "leading role that develops creative scenarios that serve to organize and assemble a" supporting cast "of those involved with a vision of strategic value development to be identified and exploited (Gupta et al., 2004).According to (Schumpeter \& Nichol, 1934), they highlighted that the process of disruptive innovation, entrepreneurship and innovation are linked. Innovation is defined as a drive to accomplish things in a more imaginative way. In the context of a business, innovation refers to the fusion of a variety of current methods that enable a firm to accomplish and outperform its competitors(Al-Ansari et al., 2014). It is all part of new technology, such as commodity efficiency, manufacturing, economies and commodities, and new corporate innovation, which is described by the OECD's new organizing strategy (Deschamps \& van Nes, 2005; Rosenbusch et al., 2011). The adoption of unique corporate objectives in a company's management procedures, staff structure, or stakeholder interests is defined by the OECD as organization innovation. For various types of development, such as generating creativity and new designs, building alternative company models, enhancing customer experiences, and increasing performance, procedures, and sales channels, several forms of entrepreneurial leadership skills are recommended (Deschamps \& van Nes, 2005). The request for innovation of the Organization is the first stage in creating or adopting organizational innovation. This creates a further pressure on entrepreneurial leaders to remain vigilant about new products and procedures in their organization, 
Review of Economics and Development Studies, Vol. 7 (3) 2021, 343-356

test them, and propose them. Innovation par excellence would be achieved by an on-going high degree of trade vigilance, but also a duty to gain and grow the expertise and skills needed to make use of these options (Park, 2005). In recent years, several findings have shown that some leadership styles (i.e. supportive, transformational and democratic etc.) have been positive in the field of innovation within the organization (Gumusluoğlu \& Ilsev, 2009; Hsiao et al., 2009; Jung et al., 2008; Jung et al., 2003; Oldham \& Cummings, 1996; Sarros et al., 2008; Tierney et al., 1999). EL is more prevalent among founding leaders than those of unfounded organizational leaders. A mixed-method research by (He et al., 2017) found that entrepreneurs are characterized and openly viewed as someone having a view, motivation, integrity and transparency. Moreover, in businesses confronting a chaotic environment, EL plays a key role and hence demands more attention to study. In recent research (Fontana \& Musa, 2017), EL was characterized as a distinctive leadership style that focuses on the development of diverse talents and on building and developing shared procedures in an organization to address an unclear business innovation model (innovation process), as well as to make systematic strategies and access innovative results (innovation performance). While this research has provided helpful insights, subsequent research suggests that entrepreneurial behaviors are more relevant in many situations, alongside participatory, supporting and transformative behaviors. Literature from recent times implies that organizations, with an increased rivalry for essential resources, must be more entrepreneurial to enhance their capability in the complex and explosive environment for the long term (Gupta et al., 2004). Researchers have thus began researching "ways to advocate entrepreneurial conduct in companies and the notion of entrepreneurial leadership is one of them in the literature" (Renko et al., 2015). (Newman et al., 2018) has verified that innovative conduct will be more convincing when people operate under a powerful entrepreneurial leader. So from the above discussion we can conclude that: H1: entrepreneurial Leadership have a significant influence on the business model innovation (BMI).

\subsection{Entrepreneurial leadership and Entrepreneurial Bricolage}

(Baker \& Nelson, 2005) identified bricolage activities as a method that some entrepreneurs "create" by combining available resources to address new challenges. Entrepreneurial behavioral theory seeks to clarify how businessmen might occasionally "do" resource constraints to recombine the available resources. Bricolage may occasionally produce "great unanticipated results" (Lévi-Strauss, 1967), but it can also lead to poor performance, implying that a reliance on bricolage in too many business sectors may interfere with a company's ability to focus on a prime opportunity. But it did not specify or evaluate certain behaviors that might undermine the advantages of bricolage.

Entrepreneurial leadership is assisting in the discovery of new and valuable bricolage prospects (Baker \& Wurgler, 2007; Baker \& Nelson, 2005) For example, by using all the social relationships it has access to, the US toy business may exploit local resources as inexpensively as feasible. Business leaders may also assist companies to decrease lock in constraints on the utilization of present resources and identify new potential applications for accessible resources by means of knowledge engagement, environmental detection and mission management (Di Domenico et al., 2010). This will help entrepreneurial leadership clarify resources and attributes and hence encourage more bricolage techniques. Thus we can make a hypothesis that:

H2: Entrepreneurial Leadership have a significant effect with entrepreneurial bricolage.

\subsection{Entrepreneurial Bricolage and Business Model Innovation}

Bricolge was frequently considered the final choice for companies addressing organizational imbalance and lack of competitiveness in its early years of adoption. For example, (Fuglsang, 2010) discovered, for example, that bricolge is a processing method that inexorably leads to productive innovation. Bricolage invites businesses to build unique value propositions by combining current and 
Review of Economics and Development Studies, Vol. 7 (3) 2021, 343-356

new capital. Since these tools are not uniform, they can be bricolaged to build new value propositions. From the preceding results, it is approved that business model significantly relates to the entrepreneurial performance (Afuah \& Tucci, 2003; George \& Bock, 2011; Zott \& Amit, 2010). According to (Phangestu et al., 2020) when entrepreneurial leadership increases the business innovation model then the start-ups getting stronger.

Entrepreneurial Bricolge, we believe, has three primary business (BMI) implications. First, by bricolaging current and new resources, companies may build a new value proposition. These resources cannot be recognized but can be used for developing new values through bricolage. A relative study of wind turbine product innovation was conducted by (Garud \& Karnøe, 2003), for example, in Denmark and the United States. They observed that Danish companies were even scouring waste products for material. They have recreated product designs based on the resources available and attained the desired aims. Conversely, companies in America concentrated on how components and parts may be made and improved on the basis of conventional designs and finally have achieved less than their Danish counterparts. This example provides a valuable reference source for entering businesses employing line by line resources that indicate that they can also play an unintended role in the development of innovative goods or services via bricolage. Thus BMI can drive business Bricolage by means of the creative value suggestion of the firm model. Second, bricolage's new value proposition may enable companies to expand beyond their market borders, re-analyze, and redefine themselves as target market segments .Bricolge can improve BMI by changing the company model's consumer categories, mediums, and customer relationships (Baker \& Nelson, 2005; Desa \& Basu, 2013). Third, bricolage might let enterprises to build new regulations and standards in the existing conditions by refusing to adopt the rules and practices of the default industry (Baker \& Nelson, 2005). In short, bricolage can help BMI by changing one or more components of the business strategy. From the above arguments we can conclude that:

H3: Entrepreneurial bricolage have a significant effect on the business model innovation.

\subsection{Bricolage is mediating the relationship of entrepreneurial leadership and business model innovation}

When institutional support or resource shortages are insufficient as a result of uncertainty, entrepreneurial bricolage (EB) acts as a change or innovation agent (Garud \& Karnøe, 2003). Bricolage is a significant method of innovation, if young companies join it instead of referring to resource limitations. EB mediates the link between entrepreneurial leadership and the innovation model of firms (Hooi et al., 2016). (Hambrick, 2007) acknowledged the influence of the senior management team on the success of a firm. Therefore, to forecast organization results, it is vital to comprehend their conduct. Managers can use a limited range of resources to implement business policies in order to increase performance and build sustained competitive advantage, according to RBV theory. In order to flourish over time, organizations, including society and the environment, need to conserve their resources. For long-term success, organizations, including society and the environment, must conserve their resources. To do so, they must also incorporate social responsibility principles into their business actions (Halabi \& Samy, 2009; Zain, 2006), and be able to design and invent solutions by repurposing available resources: engage in entrepreneurial bricolage. (Gundry et al., 2011) found that entrepreneurial bricolage mediated the relationship between disruptive innovation and the innovation environment. This study also supports the notion that bricolage improves business performance by encouraging entrepreneurial innovation, which leads to entrepreneurial leadership. However, certain subjective resource utilization efforts eventually restrict firms and make it harder for them to create innovation in business models. Entrepreneurship must thus inspire the innovative use of resources through bricolage in order to foster business model innovation. Moreover, entrepreneurial management 
Review of Economics and Development Studies, Vol. 7 (3) 2021, 343-356

in many companies can merely establish a network of resources without resulting significantly in innovation in their business models.

H4: Entrepreneurial bricolage mediates the relationship between entrepreneurial leadership and business model innovation.

\subsection{Self-efficacy moderates the relationship between entrepreneurial leadership and entrepreneurial bricolage}

According to (Hmieleski \& Corbett, 2008) a high level of entrepreneurial self-efficacy favorably moderates the association between an entrepreneurial leadership and entrepreneurial bricolage. Almost all of the study scholars have explored the direct or mediating influence of entrepreneurial self-efficacy on employees' creativity or creative behavior, but have showed no interest in exploring the moderation path for this variable. According to (Bandura et al., 1999) the self-efficacy hypothesis divides into two categories (i.e. general to specific). The generalized self-efficacy stays steady in general, but it is recognized that as it progresses toward specificity, it becomes more vulnerable to personal and contextual circumstances. (Bandura et al., 1999) The creative/ entrepreneurial self-efficacy belongs inside the specificity continuum, according to Bandura's two continuum model.

According to (Forbes, 2005; Tierney \& Farmer, 2002), creative/ entrepreneurial self-efficacy is dependent on personal and environmental characteristics and the study of (Kickul et al., 2009; McGee et al., 2009; Yang \& Cheng, 2009) and may lie on a high or low continuation, which may influence the strategies used to enhance innovative behavior among employees. (Ahlin et al., 2014; Jaiswal \& Dhar, 2015; Mokhber et al., 2016) (Hmieleski \& Corbett, 2008; Indrawati et al., 2015). Past research shown that leadership is favorably linked to the self-efficacy of employees (Aggarwal \& Krishnan, 2013; Jaiswal \& Dhar, 2015). While (Momeni et al., 2014) revealed that creative work behavior is positively connected with the self-efficacy of workers. Employees with considerable autonomy lead, in the other hand, to the capacity to carry out their jobs effectively. The moderator variable for the link between entrepreneurial leadership and entrepreneurial bricolage has therefore been assigned creative self-efficacy for workers. H5: entrepreneurial self-efficacy moderates the relationship between entrepreneurial leadership and entrepreneurial bricolage.

\section{Conceptual Framework}

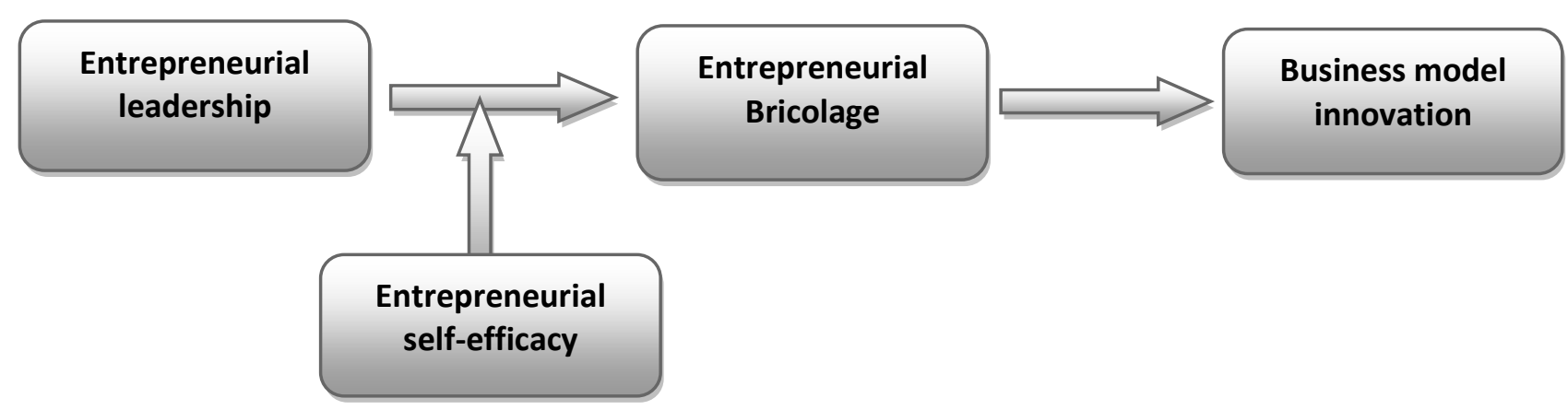

\section{Research Methodology}

\subsection{Data Collection}

For the aim to obtain data a quantitative, cross-sectional research methodology and survey (questionnaire) tool were chosen to compile data from defendants employed at the Manufacturing district of Sialkot and Gujranwala divisions, Punjab, Pakistan. Using the random sampling method, out 
Review of Economics and Development Studies, Vol. 7 (3) 2021, 343-356

of 400 questionnaire 325 were selected with the response rate of 81.25. 75 questionnaire were skipped during the screening process due to a lack of merit and were discovered anonymously not performed by people during the outcomes analysis. Following the selection process, a total of 325 questionnaires were chosen.

\subsection{Instrumentation}

This study's instrument was split into two parts. The first segment dealt with demographic and organizational facts about the respondents. The second section was divided into five parts, each with its own set of questions designed to elicit respondents' perspectives on each variable. All the items of questionnaire variable that are present in questionnaire are adopted from the previous literature. Three scale- item of entrepreneurial leadership was adapted from the (Renko et al., 2015), 4 scale-item items of entrepreneurial bricolage is adapted from the (Gundry et al., 2011; Senyard et al., 2010). 3 scale-item of business model innovation is used to adopted from the (Zott \& Amit, 2007, 2008) scale. And selfefficacy questionnaire items were adapted from (George \& Bock, 2011) article named as Self-leadership and performance outcomes: The mediating influence of self-efficacy

\section{Findings of the Study}

\subsection{Correlation Analysis}

The mean, standard deviation and correlation between the different variables are shown in Table 1. In order to assess the meaning of associations between variables, a correlation test is done. Table 1 shows that entrepreneurial leadership has positive and substantial correlations, $\mathrm{r}=0.473, \mathrm{r}=$ 0.308 and $r=0.327$, respectively, to Entrepreneurial bricolage, business Model Innovation and Entrepreneurial Self-Efficacy. In addition, the entrepreneurial self-efficacy is good with Entrepreneurial Bricolage and substantially connected with $r=0.330$. It is also shown from the data that the Entrepreneurial bricolage has a good connection with Business Model Innovation with $r=0.243$.

\section{Table 1: Mean, Standard deviation and Correlation}

\begin{tabular}{|c|c|c|c|c|c|c|}
\hline Variables & Mean & SD & $\mathbf{X}$ & $\mathbf{M}$ & $\mathbf{Y}$ & $\mathbf{W}$ \\
\hline $\begin{array}{l}\text { Entrepreneurial } \\
\text { Leadership (EL) }\end{array}$ & 4.126 & 0.688 & 1 & & & \\
\hline $\begin{array}{l}\text { Entrepreneurial } \\
\text { Bricolage (EB) }\end{array}$ & 3.914 & 0.661 & $0.473^{* *}$ & 1 & & \\
\hline $\begin{array}{l}\text { Business Model } \\
\text { Innovation (BMI) }\end{array}$ & 4.072 & 0.554 & $0.308^{* *}$ & $0.243^{* *}$ & 1 & \\
\hline $\begin{array}{ll}\text { Entrepreneurial } & \text { Self } \\
\text { Efficacy (ESE) } & \\
\end{array}$ & 4.266 & 0.667 & $0.327^{* *}$ & $0.330^{* *}$ & $0.369^{* *}$ & 1 \\
\hline
\end{tabular}

\subsection{Measurement Model}

The reliability and validity of items shown in Table 2. The values of the coefficient Cronbach alpha $(\alpha)$ were assessed for reliability. The reliability values for all dimensions, entrepreneurial leadership, entrepreneurial self-efficacy, entrepreneurial bricolage and innovation in business models are over threshold 0.70 that means all the variable design possess strong internal consistency.

For validity the Convergent validity and discriminant validity were tested. For convergent validity the factor loading and Average Variance Extracted (AVE) were analyzed. According to (Fornell 
Review of Economics and Development Studies, Vol. 7 (3) 2021, 343-356

\& Larcker, 1981) the factor loading value and the values of AVE must be more than 0.50 for each construct to confirm the presence of validity. In table 2, Factor loading values for each item are between 0.549 and 0.875 indicating that all values are over the minimum threshold as set by (Hair et al., 2010). Also, the values of the extracted average variance (AVE) exceed 0.50.

Next for the discriminant validity, the values of Cronbach's alpha of each construct and its correlations with other model variables were compared. The greater values of the alpha than the average of its correlations with other variables, indicates the presence of discriminant validity (Ghiselli et al., 1981; Sila \& Ebrahimpour, 2005). The positive values of discriminant validity in Table 2, indicated the evidence of the discriminant validity. Thus, all the table findings suggest that internal reliability and validity of the measuring model is available.

Table 2: Reliability and Validity Analysis

\begin{tabular}{|l|l|l|l|l|l|}
\hline Variables & Items & $\begin{array}{l}\text { Loading Values } \\
(\lambda)\end{array}$ & $\begin{array}{l}\text { Cronbach's } \\
\text { Alpha ( } \boldsymbol{\alpha})\end{array}$ & $\begin{array}{l}\text { Average } \\
\text { Variance } \\
\text { Extracted } \\
\text { (AVE) }\end{array}$ & $\begin{array}{l}\text { Discriminant } \\
\text { validity }\end{array}$ \\
\hline $\begin{array}{l}\text { Entrepreneurial } \\
\text { Leadership (EL) }\end{array}$ & 3 & $\begin{array}{l}0.79,0.875 \\
0.574\end{array}$ & 0.774 & 0.573 & 0.405 \\
\hline $\begin{array}{l}\text { Entrepreneurial } \\
\text { Bricolage (EB) }\end{array}$ & 4 & $\begin{array}{l}0.615,0.698, \\
0.661,0.527\end{array}$ & 0.713 & 0.539 & 0.365 \\
\hline $\begin{array}{l}\text { Business Model } \\
\text { Innovation (BMI) }\end{array}$ & 3 & $\begin{array}{l}0.607,0.725, \\
0.632\end{array}$ & 0.710 & 0.541 & 0.403 \\
\hline $\begin{array}{l}\text { Entrepreneurial } \\
\text { Self Efficacy } \\
\text { (ESE) }\end{array}$ & 9 & $\begin{array}{l}0.661,0.692 \\
0.546,0.592 \\
0.568,0.658\end{array}$ & 0.829 & 0.665 & 0.489 \\
& & $\begin{array}{l}0.590,0.565 \\
0.549\end{array}$ & & \\
\hline
\end{tabular}

\subsection{Mediation Analysis}

The mediation analyses were performed using the methodology of (Baron \& Kenny, 1986). In this respect, firstly, the direct effect of the independent (entrepreneurial leadership) to the dependent (Business model innovation) variable and then the indirect effect between the two variables should be assessed by means of a mediating variable (Entrepreneurial Bricolage). The findings of latent direct and indirect impact variables are shown in Table 3.

Direct Effect: The direct association between dependent and independent variables has resulted in an important and favorable impact of entrepreneurial leadership on business-model innovation. This substantial result allowed the mediation test to be analyzed. The findings also lend support to the theoretical connections between enterprise leadership and enterprise bricolage, which benefited and significantly improved the business innovation model.

Indirect Effect: The value of the beta co-efficient then changed from 0.191 to 0.042 in $p<0.01$, and remained significant by establishing a mediation variable Entrepreneurial Bricolagein between independent and dependent variable. The results therefore revealed that the entrepreneurial bricolage is somewhat mediated between entrepreneurial leadership and the Innovation Business Model. 
Review of Economics and Development Studies, Vol. 7 (3) 2021, 343-356

Table 3: Direct and Indirect Effects

\begin{tabular}{|c|c|c|c|c|}
\hline Hypotheses & Coefficient & SE & $95 \% \mathrm{CI}$ & Findings \\
\hline \multicolumn{5}{|l|}{ Total effect } \\
\hline $\mathrm{EL} \rightarrow \mathrm{BMI}$ & 0.233 & 0.043 & $(0.109,0.278)$ & Significant \\
\hline \multicolumn{5}{|l|}{ Direct Effect } \\
\hline $\mathrm{EL} \rightarrow \mathrm{BMI}$ & 0.191 & 0.041 & $(0.153,0.314)$ & Significant \\
\hline $\mathrm{EL} \rightarrow \mathrm{EB}$ & 0.190 & 0.043 & $(0.109,0.278)$ & Significant \\
\hline $\mathrm{EB} \rightarrow \mathrm{BMI}$ & 0.780 & 0.036 & $(0.188,0.327)$ & Significant \\
\hline \multicolumn{5}{|c|}{ Indirect Effect Bootstrap result } \\
\hline $\mathrm{EL} \rightarrow \mathrm{EB} \rightarrow \mathrm{BMI}$ & 0.042 & 0.016 & $(0.070,0.111)$ & $\begin{array}{l}\text { Significant } \\
\text { (Partial } \\
\text { Mediation) }\end{array}$ \\
\hline
\end{tabular}

\subsection{Moderated Mediation Analysis}

Process Macro Model 7 was used to analyze the moderating effect of entrepreneurial selfefficacy between Entrepreneurial leadership and Entrepreneurial Bricolage. The overall results supported the proposed hypothesized moderated mediation model as shown in table 4 . The result of R2 $=0.258 * *$ first reveals that 25.8 percent of the variation to Entrepreneurial Bricolage is attributed to moderation in the case of Entrepreneurial Bricolage as an outcome variable. The relationship to the interacting action value $(\beta=0.09, \mathrm{CI} 0.18$ to 0.08$)$ with mediator Entrepreneurial Bricolage demonstrates a favorable and significant one. As a result, increased business self-efficiency in the workplace will significantly boost employee bricolage. Secondly, the positive direct impact of X on Y ( $\beta$ = 0.39) was also found.

Next, there are three distinct levels of ESE moderator: low, medium and high level of EL conditional indirect effects on BPI through EB. In Table 4, all the conditional indirect effects of moderator ESE were demonstrated to be substantial. With $(\beta=0.46 ; \beta=0.49)$ and $\beta=0.520)$. The moderated Meditation Value Index finally confirmed that EL * ESE supported the moderated overall mediation model with an indirect impact of 0.06 and bootstrap CI (0.19 to 0.20$)$. The results have therefore shown that the favorable influence of EL on BMI via EB grows as ESE in employee's increases.

Table 4: Moderated Mediation Results

\begin{tabular}{|c|c|c|c|c|c|c|c|}
\hline Relations & $\mathrm{R}^{2}$ & $\beta$ & SE & $\mathrm{P}$ & LLCI & ULCI & Decision \\
\hline $\mathrm{EL} \rightarrow \mathrm{EB}$ & \multirow[t]{3}{*}{$0.258^{* *}$} & 0.79 & 0.15 & 0.00 & 0.53 & 1.10 & Sig \\
\hline $\mathrm{ESE} \rightarrow \mathrm{EB}$ & & 0.45 & 0.14 & 0.00 & 0.29 & 0.78 & Sig \\
\hline$E L^{*} \mathrm{ESE}=\mathrm{X}^{*} \mathrm{~W}(\mathrm{Int})$ & & 0.09 & 0.04 & 0.00 & 0.18 & 0.08 & Sig \\
\hline $\mathrm{EL} \rightarrow \mathrm{BMI}$ & \multirow[t]{2}{*}{$0.101^{* *}$} & 0.32 & 0.06 & 0.00 & 0.29 & 0.54 & Sig \\
\hline $\mathrm{EB} \rightarrow \mathrm{BMI}$ & & 0.53 & 0.08 & 0.00 & 0.48 & 0.78 & Sig \\
\hline \multicolumn{8}{|l|}{ Direct effect: } \\
\hline $\mathrm{EL} \rightarrow \mathrm{BMI}$ & & 0.39 & 0.06 & 0.00 & 0.31 & 0.56 & Sig \\
\hline \multicolumn{8}{|c|}{ Conditional indirect effect of $X$ on $Y$ via $M$} \\
\hline \multicolumn{8}{|l|}{ ESE levels } \\
\hline Low & & 0.46 & 0.06 & & 0.17 & 0.42 & Sig \\
\hline Med & & 0.49 & 0.04 & & 0.15 & 0.34 & Sig \\
\hline High & & 0.52 & 0.05 & & 0.14 & 0.28 & Sig \\
\hline
\end{tabular}


Review of Economics and Development Studies, Vol. 7 (3) 2021, 343-356

\begin{tabular}{|l|l|l|l|l|l|l|}
\hline Index of moderated mediation & & & & & & $\begin{array}{l}\text { Sig } \\
\text { (Accepte } \\
\text { d) }\end{array}$ \\
\hline $\begin{array}{l}\text { ESE } \\
\beta=\text { unstandardized regression coefficient; SE = standard error; LL = lower limit; CI = 95 \% } \\
\text { confidence interval; UL = upper limit }\end{array}$ \\
\hline
\end{tabular}

\section{Conclusion and Implications of the Study}

It is a complicated and frequently unpredictable entrepreneurial climate. As a result, no entrepreneur has the ability to predict all circumstance he or she will encounter properly. Likewise, no entrepreneur can thrive by getting things on the fly. Effective business innovation model tends to involve a mixture of planned and spontaneous actions - a problem space that is typical of spontaneous activity. Trust in entrepreneurial capabilities is important in order to succeed in this at the time of entrepreneurial bricolage. Entrepreneurs must have self-efficay and he should must be confident in their capacity to identify important resources and how to recombine to solve issues and take advantage of opportunities. The major aim of this research is to inspecting the basic impact of entrepreneurial leadership on business model innovation with the mediating function of entrepreneurial bricolage and the moderating influence of entrepreneurial self-efficacy. The findings of this study show that the presence of entrepreneurial self-efficacy at all levels has a positive impact on the impact of entrepreneurial leadership on increasing bricolage and developing the company's business model innovation. This study demonstrates that entrepreneurial leadership can be viewed as an innovation perspective and a critical role in business bricolage. Almost all of the researchers in the study focused on the mediation influence of entrepreneurial self-efficacy on creativity and innovative performance of individuals, but none studied the moderation route to this variable.

\section{Discussion}

The primary goal of the study is to investigate the effects of entrepreneurial leadership on the development of business model innovation by mediating the entrepreneurial bricolage of Pakistan's manufacturing workers. A recent study found that entrepreneurial leadership can create an innovation model and have a significant impact on entrepreneurial bricolage. Almost all research students researched, but showed little interest in the moderation path for this variable, but only studied the direct or mediating impact on the creativity or the creative behavior of workers on entrepreneurial selfefficacy. As a result, the study also demonstrates that entrepreneurial leadership motivates its employees to engage in entrepreneurial bricolage, which is consistent with previous research. As a result, the findings of this study indicate that the presence of self-efficacy among entrepreneurial leadership and entrepreneurial bricolage has significantly moderated their relationship.

\section{Future directions and limitations}

About the fact that this study makes important theoretical and functional contributions, it has many drawbacks. Lack of knowledge of workers about these terms that are working in manufacturing sector is the one of the major limitation of the study. To begin, the data collection process is solely based on self-report questionnaires. Despite criticism from some researchers, this approach was considered appropriate due to the complexities involved with the unbiased evaluation of any of these variables. Even so, prospective studies should look at ways to collect data from multiple informants in order to reduce the risk of response bias. Second, this study used one-short or cross-sectional data, which makes it impossible for organization to compare the before and after effects of entrepreneurial bricolage on business innovation model and on firms who adopts entrepreneurial leadership. As a result, for future studies, a longitudinal analysis or qualitative interview with top management is 


\section{Review of Economics and Development Studies, Vol. 7 (3) 2021, 343-356}

recommended, where more detailed conclusions can be produced after reforms are implemented.

\section{References}

Afuah, A., \& Tucci, C. L. (2003). Internet business models and strategies: Text and cases (Vol. 2). McGraw-Hill New York.

Aggarwal, J., \& Krishnan, V. R. (2013). Impact of transformational leadership on follower's selfefficacy: Moderating role of follower's impression management. Management and Labour Studies, 38(4), 297-313.

Ahlin, B., Drnovšek, M., \& Hisrich, R. D. (2014). Entrepreneurs' creativity and firm innovation: the moderating role of entrepreneurial self-efficacy. Small Business Economics, 43(1), 101-117.

Al-Ansari, N., Ali, A., \& Knutsson, S. (2014). Present conditions and future challenges of water resources problems in Iraq. Journal of Water Resource and Protection, 6(12), 1066-1098.

Aldrich, H. (1999). Organizations evolving. Sage.

Aldrich, W., Crawford, C., \& Aid, A. S. (1941). Second report upon cold storage of date pollen. Date Growers' Institute, 18(5).

Baker, M., \& Wurgler, J. (2007). Investor sentiment in the stock market. Journal of Economic Perspectives, 21(2), 129-152.

Baker, T., \& Nelson, R. E. (2005). Creating something from nothing: Resource construction through entrepreneurial bricolage. Administrative science quarterly, 50(3), 329-366.

Bandura, A., Freeman, W., \& Lightsey, R. (1999). Self-efficacy: The exercise of control. In: Springer.

Baron, R. A. (1998). Cognitive mechanisms in entrepreneurship: Why and when enterpreneurs think differently than other people. Journal of business venturing, 13(4), 275-294.

Baum, J. R., \& Locke, E. A. (2004). The relationship of entrepreneurial traits, skill, and motivation to subsequent venture growth. Journal of applied psychology, 89(4), 587.

Baum, J. R., Locke, E. A., \& Smith, K. G. (2001). A multidimensional model of venture growth. Academy of management journal, 44(2), 292-303.

Bourgeois III, L. J., \& Eisenhardt, K. M. (1988). Strategic decision processes in high velocity environments: Four cases in the microcomputer industry. Management science, 34(7), 816835 .

Boyd, N. G., \& Vozikis, G. S. (1994). The influence of self-efficacy on the development of entrepreneurial intentions and actions. Entrepreneurship theory and practice, 18(4), 63-77.

Bradley, D. E., \& Roberts, J. A. (2004). Self-employment and job satisfaction: investigating the role of self-efficacy, depression, and seniority. Journal of small business management, 42(1), 3758.

Brüderl, J., Preisendörfer, P., \& Ziegler, R. (1992). Survival chances of newly founded business organizations. American sociological review, 227-242.

Covin, J. G., \& Slevin, D. P. (1988). The influence of organization structure on the utility of an entrepreneurial top management style. Journal of management studies, 25(3), 217-234.

Covin, J. G., \& Slevin, D. P. (1989). Strategic management of small firms in hostile and benign environments. Strategic management journal, 10(1), 75-87.

Desa, G., \& Basu, S. (2013). Optimization or bricolage? Overcoming resource constraints in global social entrepreneurship. Strategic entrepreneurship journal, 7(1), 26-49.

Deschamps, J., \& van Nes, J. (2005). Developmental regulation of the Hox genes during axial morphogenesis in the mouse. Development, 132(13), 2931-2942.

Fontana, A., \& Musa, S. (2017). The impact of entrepreneurial leadership on innovation management and its measurement validation. International Journal of Innovation Science. 


\section{Review of Economics and Development Studies, Vol. 7 (3) 2021, 343-356}

Forbes, D. P. (2005). The effects of strategic decision making on entrepreneurial self-efficacy. Entrepreneurship theory and practice, 29(5), 599-626.

Fornell, C., \& Larcker, D. F. (1981). Evaluating structural equation models with unobservable variables and measurement error. Journal of Marketing Research, 18(1), 39-50.

Fuglsang, L. (2010). Bricolage and invisible innovation in public service innovation. Journal of Innovation Economics Management(1), 67-87.

Garud, R., \& Karnøe, P. (2003). Bricolage versus breakthrough: distributed and embedded agency in technology entrepreneurship. Research Policy, 32(2), 277-300.

George, G., \& Bock, A. J. (2011). The business model in practice and its implications for entrepreneurship research. Entrepreneurship theory and practice, 35(1), 83-111.

Ghiselli, G., Schaefer, E. J., Gascon, P., \& Breser, H. (1981). Type III hyperlipoproteinemia associated with apolipoprotein E deficiency. Science, 214(4526), 1239-1241.

Gumusluoğlu, L., \& Ilsev, A. (2009). Transformational leadership and organizational innovation: The roles of internal and external support for innovation. Journal of Product Innovation Management, 26(3), 264-277.

Gundry, L. K., Kickul, J. R., Griffiths, M. D., \& Bacq, S. C. (2011). Creating social change out of nothing: The role of entrepreneurial bricolage in social entrepreneurs' catalytic innovations. In Social and sustainable entrepreneurship. Emerald Group Publishing Limited.

Gupta, V., MacMillan, I. C., \& Surie, G. (2004). Entrepreneurial leadership: developing and measuring a cross-cultural construct. Journal of business venturing, 19(2), 241-260.

Hair, P. S., Echague, C. G., Sholl, A. M., Watkins, J. A., Geoghegan, J. A., Foster, T. J., \& Cunnion, K. M. (2010). Clumping factor A interaction with complement factor I increases C3b cleavage on the bacterial surface of Staphylococcus aureus and decreases complement-mediated phagocytosis. Infection and immunity, 78(4), 1717-1727.

Halabi, A. K., \& Samy, M. (2009). Corporate social responsibility (CSR) reporting: a study of selected banking companies in Bangladesh. Social responsibility journal.

Hambrick, D. C. (2007). Upper echelons theory: An update. In: Academy of Management Briarcliff Manor, NY 10510.

He, L., Standen, P., \& Coetzer, A. (2017). The perceived personal characteristics of entrepreneurial leaders. Small Enterprise Research, 24(2), 97-119.

Hmieleski, K. M., \& Corbett, A. C. (2008). The contrasting interaction effects of improvisational behavior with entrepreneurial self-efficacy on new venture performance and entrepreneur work satisfaction. Journal of business venturing, 23(4), 482-496.

Hooi, H. C., Ahmad, N. H., Amran, A., \& Rahman, S. A. (2016). The functional role of entrepreneurial orientation and entrepreneurial bricolage in ensuring sustainable entrepreneurship. Management research review.

Hsiao, H.-C., Chang, J.-C., \& Tu, Y.-L. (2009). The influence of transformational leadership and support for innovation on organizational innovation: from the vocational high school teachers' perspective. 2009 IEEE International Conference on Industrial Engineering and Engineering Management,

Huang, S., Ding, D., \& Chen, Z. (2014). Entrepreneurial Leadership and Performance in C hinese New Ventures: A Moderated Mediation Model of Exploratory Innovation, Exploitative Innovation and Environmental Dynamism. Creativity and Innovation Management, 23(4), 453-471.

Indrawati, N. K., Salim, U., \& Djawahir, A. H. (2015). Moderation effects of entrepreneurial selfefficacy in relation between environmental dimensions and entrepreneurial alertness and the effect on entrepreneurial commitment. Procedia-Social and Behavioral Sciences, 169, 


\section{Review of Economics and Development Studies, Vol. 7 (3) 2021, 343-356}

13-22.

Jaiswal, N. K., \& Dhar, R. L. (2015). Transformational leadership, innovation climate, creative selfefficacy and employee creativity: A multilevel study. International Journal of Hospitality Management, 51, 30-41.

Judge, T. A., \& Bono, J. E. (2001). Relationship of core self-evaluations traits-self-esteem, generalized self-efficacy, locus of control, and emotional stability-with job satisfaction and job performance: A meta-analysis. Journal of applied psychology, 86(1), 80.

Jung, D. D., Wu, A., \& Chow, C. W. (2008). Towards understanding the direct and indirect effects of CEOs' transformational leadership on firm innovation. The leadership quarterly, 19(5), 582-594.

Jung, D. I., Chow, C., \& Wu, A. (2003). The role of transformational leadership in enhancing organizational innovation: Hypotheses and some preliminary findings. The leadership quarterly, 14(4-5), 525-544.

Kickul, J., Gundry, L. K., Barbosa, S. D., \& Whitcanack, L. (2009). Intuition versus analysis? Testing differential models of cognitive style on entrepreneurial self-efficacy and the new venture creation process. Entrepreneurship theory and practice, 33(2), 439-453.

Krueger Jr, N. F., \& Brazeal, D. V. (1994). Entrepreneurial potential and potential entrepreneurs. Entrepreneurship theory and practice, 18(3), 91-104.

Lévi-Strauss, C. (1967). The story of Asdiwal. The structural study of myth and totemism, 4, 1-47.

Lindgardt, Z., Reeves, M., Stalk, G., \& Deimler, M. S. (2009). Business model innovation. When the Game Gets Tough, Change the Game, The Boston Consulting Group, Boston, MA, 118.

Markman, G. D., Balkin, D. B., \& Baron, R. A. (2002). Inventors and new venture formation: The effects of general self-efficacy and regretful thinking. Entrepreneurship theory and practice, 27(2), 149-165.

McGee, J. E., Peterson, M., Mueller, S. L., \& Sequeira, J. M. (2009). Entrepreneurial self-efficacy: Refining the measure. Entrepreneurship theory and practice, 33(4), 965-988.

Miller, D. (2011). Miller (1983) revisited: A reflection on EO research and some suggestions for the future. Entrepreneurship theory and practice, 35(5), 873-894.

Mokhber, M., Tan, G. G., Vakilbashi, A., Zamil, N. A. M., \& Basiruddin, R. (2016). Impact of Entrepreneurial Leadership on Organization Demand for Innovation: Moderating Role of Employees' Innovative Self-Efficacy. International Review of Management and Marketing, 6(3).

Momeni, M., Ebrahimpour, H., \& Ajirloo, M. B. (2014). THE EFFECT OF EMPLOYEES'SELFEFFICACY ON INNOVATIVE WORK BEHAVIOR AT SOCIAL SECURITY ORGANIZATION EMPLOYEES IN ARDABIL PROVINCE. Kuwait Chapter of the Arabian Journal of Business and Management Review, 3(8), 29.

Newman, A., Herman, H., Schwarz, G., \& Nielsen, I. (2018). The effects of employees' creative self-efficacy on innovative behavior: The role of entrepreneurial leadership. Journal of Business Research, 89, 1-9.

Oldham, G. R., \& Cummings, A. (1996). Employee creativity: Personal and contextual factors at work. Academy of Management journal, 39(3), 607-634.

Palalic, R. (2017). The phenomenon of entrepreneurial leadership in gazelles and mice: A qualitative study from Bosnia and Herzegovina. World Review of Entrepreneurship, Management and Sustainable Development, 13(2-3), 211-236.

Park, J. S. (2005). Opportunity recognition and product innovation in entrepreneurial hi-tech start-ups: a new perspective and supporting case study. Technovation, 25(7), 739-752.

Phangestu, J., Kountur, R., \& Prameswari, D. A. (2020). The Moderating Effect of Entrepreneurial Leadership and Competitive Advantage on the Relationship Bbetween Business Model 
Review of Economics and Development Studies, Vol. 7 (3) 2021, 343-356

Innovation and Startup Performance. Journal of Business and Retail Management Research, 14(3).

Renko, M., El Tarabishy, A., Carsrud, A. L., \& Brännback, M. (2015). Understanding and measuring entrepreneurial leadership style. Journal of small business Management, 53(1), 54-74.

Rosenbusch, N., Brinckmann, J., \& Bausch, A. (2011). Is innovation always beneficial? A metaanalysis of the relationship between innovation and performance in SMEs. Journal of business venturing, 26(4), 441-457.

Sarros, J. C., Cooper, B. K., \& Santora, J. C. (2008). Building a climate for innovation through transformational leadership and organizational culture. Journal of Leadership \& Organizational Studies, 15(2), 145-158.

Schumpeter, J. A., \& Nichol, A. (1934). Robinson's economics of imperfect competition. Journal of political economy, 42(2), 249-259.

Senyard, J., Baker, T., \& Steffens, P. (2010). Entrepreneurial bricolage and firm performance: Moderating effects of firm change and innovativeness. Annual Meeting of the Academy of Management,

Shepherd, D. A., Douglas, E. J., \& Shanley, M. (2000). New venture survival: Ignorance, external shocks, and risk reduction strategies. Journal of business venturing, 15(5-6), 393-410.

Sila, I., \& Ebrahimpour, M. (2005). Critical linkages among TQM factors and business results. International journal of operations \& production management.

Stajkovic, A. D., \& Luthans, F. (1998). Self-efficacy and work-related performance: A metaanalysis. Psychological bulletin, 124(2), 240.

Stevenson, H. H. (1983). A perspective on entrepreneurship (Vol. 13). Harvard Business School Cambridge, MA.

Tierney, P., \& Farmer, S. M. (2002). Creative self-efficacy: Its potential antecedents and relationship to creative performance. Academy of management journal, 45(6), 1137-1148.

Tierney, P., Farmer, S. M., \& Graen, G. B. (1999). An examination of leadership and employee creativity: The relevance of traits and relationships. Personnel psychology, 52(3), 591-620.

Trimi, S., \& Berbegal-Mirabent, J. (2012). Business model innovation in entrepreneurship. International Entrepreneurship and Management Journal, 8(4), 449-465.

Wiklund, J., \& Shepherd, D. (2005). Entrepreneurial orientation and small business performance: a configurational approach. Journal of business venturing, 20(1), 71-91.

Yang, H.-L., \& Cheng, H.-H. (2009). Creative self-efficacy and its factors: An empirical study of information system analysts and programmers. Computers in Human Behavior, 25(2), 429438.

Yukl, G., Mahsud, R., Hassan, S., \& Prussia, G. E. (2013). An improved measure of ethical leadership. Journal of leadership \& organizational studies, 20(1), 38-48.

Zahra, S. A. (1991). Predictors and financial outcomes of corporate entrepreneurship: An exploratory study. Journal of business venturing, 6(4), 259-285.

Zain, M. M., Mohammad, R., \& Ibrahim, M. K. (2006). Corporate social responsibility

disclosure in Malaysia. U. P. C. (UPENA).

Zhao, H., Seibert, S. E., \& Hills, G. E. (2005). The mediating role of self-efficacy in the development of entrepreneurial intentions. Journal of applied psychology, 90(6), 1265.

Zott, C., \& Amit, R. (2007). Business model design and the performance of entrepreneurial firms. Organization Science, 18(2), 181-199.

Zott, C., \& Amit, R. (2008). The fit between product market strategy and business model: Implications for firm performance. Strategic management journal, 29(1), 1-26.

Zott, C., \& Amit, R. (2010). Business model design: An activity system perspective. Long range planning, 43(2-3), 216-226. 